Mini Review

\title{
Effects of aldosterone and mineralocorticoid receptor antagonism on cardiac ion channels in the view of upstream therapy of atrial fibrillation
}

\author{
Roman Laszlo, Kerstin Bentz and Juergen Schreieck \\ Medizinische Klinik III, Kardiologie und Kreislauferkrankungen, Eberhard Karls Universität Tuebingen, Tuebingen, Germany
}

\begin{abstract}
Atrial fibrillation (AF) is the most common sustained arrhythmia in man. Over the past years, importance of the renin-angiotensin-aldosterone system in AF pathophysiology has been recognized. Lately, the role of aldosterone in AF pathophysiology and mineralocorticoid receptor (MR) antagonism in "upstream" AF treatment is discussed with special regards concerning the effects on AF-induced structural remodeling. However, there is more and more evidence that MR antagonism also influences atrial electrophysiology and, respectively, AF-induced electrical remodeling, whereas the molecular mechanisms are almost unknown.

The aim of this mini-review is to give an overview about the role of aldosterone in AF pathophysiology in principle and to summarize current available data concerning affection of cardiac ion channels by aldosterone and MR antagonism. Finally, as modulation of oxidative stress is discussed as one main therapy principle of "upstream" treatment of AF, potential mechanisms how modulation of oxidative stress by aldosterone and accordingly MR antagonism might alter atrial ion currents are delineated.

Summarized, publications concerning potential mechanisms of aldosterone- and MR antagonismmodulated cardiac ion channels in various experimental settings are almost exclusively limited to the ventricular level and, partly, they are also contradictorily. Translation of these data to the atria is problematic because atrial and ventricular electrophysiology exhibit remarkable differences. It can be concluded that further research on the "atrial level" is needed in order to clarify the potential impact of the affection of atrial ion channels by aldosterone and accordingly MR antagonism in "upstream" therapy of AF.
\end{abstract}

Key words: Atrial fibrillation - Atrial remodeling - Aldosterone - Mineralocorticoid receptor antagonism - Upstream therapy

\section{Introduction}

Atrial fibrillation (AF) is the most common sustained arrhythmia in man (Fuster et al. 2006). It is characterized by a variety of electrophysiological, mechanical and structural changes caused by the arrhythmia itself. This process termed "atrial remodeling in atrial fibrillation" is a time-dependent adaptive regulation mechanism promoting maintenance

Correspondence to: Roman Laszlo, Medizinische Klinik III, Kardiologie und Kreislauferkrankungen, Eberhard Karls Universität Tuebingen, Otfried-Mueller-Strasse 10, D 72076 Tuebingen, Germany

E-mail: roman.laszlo@gmx.de of cell homeostasis after arrhythmia onset (Wijffels et al. 1995; Allessie et al. 2002). Progressive shortening, reduced rate-adaption and increased heterogeneity of atrial effective refractory period are characteristic features of in vivo electrophysiological alterations in AF which have been studied extensively in several animal models and humans (Workman et al. 2008). Many of these observations can be explained by influence of AF on atrial ion channels and their regulative mechanisms (Nattel et al. 2008). For example, a reduced amplitude of the L-type calcium current $\left(\mathrm{I}_{\mathrm{Ca}, \mathrm{L}}\right)$ amplitude can be observed (Allessie et al. 2002). Atrial remodeling begins within a few hours after arrhythmia onset (Bosch et al. 2003; Laszlo et al. 2008). Over the past years, importance of the renin-angiotensin-aldosterone system (RAAS) in AF 
pathophysiology has been recognized (Heusch and Schulz 2006) and provides a basis for the so-called "upstream" therapy of AF by targeting signalling pathways involved in AF pathophysiology. For example, RAAS-blockage with angiotensin-converting-enzyme-inhibitors or angiotensin-II type 1 receptor antagonists seems to be useful in AF treatment (Krishnamoorthy and Lip 2009). Lately, the role of aldosterone in AF pathophysiology and accordingly mineralocorticoid receptor (MR) antagonism as a new therapeutic principle in $\mathrm{AF}$ treatment are discussed with special regards concerning the effects on AF-induced structural remodeling (Goette et al. 2007). However, there is also some evidence that MR antagonism influences atrial electrophysiology and, respectively, AF-induced electrical remodeling (Shroff et al. 2006) whereas the molecular mechanisms are unknown to a large extent.

Theoretically, the influence of aldosterone or MR antagonism on structural remodeling might also have indirect electrophysiological consequences: for example atrial conduction velocity also depends on the degree of atrial fibrosis (Workman et al. 2008).

A significant proportion of the effect of aldosterone and accordingly of MR antagonism on atrial electrophysiology might be mediated by another potential mechanism - the affection of atrial ion channels or their regulative mechanisms, as a balanced interaction of a variety of ion currents is the molecular basis of atrial or ventricular electrophysiology as a whole (Nerbonne and Kass 2005). Basal current density of each ion channel is mediated by a complex interaction between various signalling cascades changing ion channel expression in the cell membrane and/or influencing biophysical channel properties. In turn, these signalling cascades can be altered due to the impact of aldosterone or MR antagonism on various endogenous states (for example cellular redox state (Wagner et al. 2008)) or, respectively, local and systemic regulatory systems (e.g. RAAS (Lemarie et al. 2008), cardiac ryanodine receptor activity (Gomez et al. 2009), blood pressure, blood potassium levels or acid-base homeostasis (Zannad 1991; Wehling et al. 1998; Stier et al. 2002; Struthers and MacDonald 2004; McManus et al. 2008; Ovaert et al. 2010)).

The aim of this mini-review is to give a short overview about the role of aldosterone in AF pathophysiology in principle and to summarize current available data concerning the affection of cardiac ion channels by aldosterone and MR antagonism in various experimental settings. Finally, since modulation of oxidative stress is discussed as one main therapy principle of "upstream" treatment of AF with MR antagonists (Pitt et al. 2003b; Chai and Danser 2006; Cachofeiro et al. 2008), we delineate potential mechanisms how modulation of oxidative stress by aldosterone and accordingly $\mathrm{MR}$ antagonism might also alter atrial ion currents.

\section{Potential role of aldosterone in AF pathophysiology}

Serum aldosterone levels are elevated in patients with persistent $\mathrm{AF}$ (Goette et al. 2001) and there is a positive correlation between the fall in aldosterone concentration 24 hours after successful cardioversion and maintenance of sinus rhythm during 30 days of observation (Wozakowska-Kaplon et al. 2010). Compared to age-, gender- and blood pressurematched control persons with essential hypertension, patients with primary hyperaldosteronism show a 12 -fold greater risk of AF (Milliez et al. 2005). A polymorphism of aldosterone synthase gene associated with increased aldosterone activity seems to predispose to clinical AF in patients with congestive heart failure (CHF) (Amir et al. 2008). A small study in 25 patients suggested an up-regulation of mineralocorticoid receptors and 11- $\beta$-hydroxysteroid dehydrogenase type 2 (which mediates selectivity of aldosterone binding to mineralocorticoid receptor (Chai and Danser 2006)) in human atrial fibrillation (Pei et al. 2007). In CHF, aldosterone production is increased due to RAAS activation.

Firstly, aldosterone seems to promote inflammation and oxidative stress (Chai and Danser 2006), processes that have been also implicated in atrial remodeling in AF (Korantzopoulos et al. 2003; Issac et al. 2007). Secondly, on ventricular level, increased aldosterone concentration seems to result in myocardial and vascular fibrosis in terms of an adverse ventricular structural remodeling (Struthers et al. 2004). Thus, mineralocorticoid receptor stimulation might be also involved in structural remodeling of the AF substrate associated with CHF (Li et al. 2001). Even independent from CHF, in an experimental study by Zhao et al. (2010), spironolactone treatment prevented myocardial apoptosis, myolysis, atrial fibrosis and dilatation in a dog model of long-term ( 6 weeks) rapid atrial pacing-induced structural remodeling.

Acting on the assumption of a beneficial effect of aldosterone receptor antagonism on ventricular electrophysiology particularly in congestive heart failure (Pitt et al. 1999, 2003a), effects of a selective MR blockade with eplerenone on inducibility of atrial tachycardias were studied by Shroff et al. (2006) in a canine model of CHF induced by rapid ventricular pacing. As a main result, eplerenone suppressed the inducibility of sustained atrial tachyarrhythmias. In addition, direct impact of eplerenone on atrial electrophysiology was demonstrated for the first time; eplerenone prolonged effective refractory period in some regions of the atrium remodeled by CHF (but not in normal atrium).

\section{Effects of aldosterone and mineralocorticoid receptor antagonism on cardiac ion channels}

In principle, it is important to differentiate between genomic and non-genomic actions when discussing effects of aldoster- 
one mediated via MR (Chai and Danser 2006). Non-genomic effects such as direct pharmacological interaction with ion channels can be observed shortly after drug exposure; for example intravenous administration of aldosterone led to a lengthening of monophasic atrial action potentials in patients with supraventricular arrhythmias within 4-6 minutes (Tillmann et al. 2002). Potentially mediated by direct block of repolarizing potassium currents by spironolactone or its main metabolite canrenoic acid (Caballero et al. 2003; Gomez et al. 2005), spironolactone also prolonged action potential duration in rabbit and rat multicellular preparations (Briggs and Holland 1959; Coraboeuf and Deroubaix 1974). Finally, acute application of canrenoic acid reduced L-type calcium current $\mathrm{I}_{\mathrm{Ca}, \mathrm{L}}$ in ventricular myocytes of male Wistar rats (Costa et al. 2009). Table 1 summarizes the non-genomic effects of aldosterone and MR antagonism on cardiac electrophysiology.

\section{Genomic effects on the ventricular level}

In contrast to the non-genomic effects, genomic effects are due to alterations of protein synthesis and can be initially observed after hours. Chronic aldosterone exposition of ventricular myocytes resulted in a prolongation of action potential in mice (Boixel et al. 2006) and rats (MartinFernandez et al. 2009). In a transgenic mouse model with conditional cardiac-specific overexpression of human mineralocorticoid receptor, mice exhibited a high rate of death due to life-threatening ventricular arrhythmias. In turn, these arrhythmias were prevented by spironolactone treatment (Ouvrard-Pascaud et al. 2005). Mediated via $\mathrm{MR}$, aldosterone induced an upregulation of $\mathrm{I}_{\mathrm{Ca}, \mathrm{L}}$ with no concomitant alterations of its biophysical properties through a specific genomic pathway in cultured adult rat ventricular myocytes (Benitah and Vassort 1999). Furthermore, non-genomic effects of aldosterone on $\mathrm{I}_{\mathrm{Ca}, \mathrm{L}}$ were excluded and co-incubation with spironolactone blunted upregulation of $\mathrm{I}_{\mathrm{Ca}, \mathrm{L}}$, possible effects of spironolactone on the channel's biophysical properties were not described. Similar effects of aldosterone on current density and, respectively, the missing effect on biophysical properties of $\mathrm{I}_{\mathrm{Ca}, \mathrm{L}}$ were obtained in ventricular neonatal rat cardiomyocytes (Lalevee et al. 2005). Correlation of $\mathrm{I}_{\mathrm{Ca}, \mathrm{L}}$ current density and plasma level of aldosterone was demonstrated

Table 1. Non-genomic effects of aldosterone or MR antagonism on cardiac electrophysiology in various experimental settings

\begin{tabular}{lll}
\hline & \multicolumn{1}{c}{ Atrium } & Ventricle \\
\hline Briggs et al. 1959 & $\begin{array}{l}\text { Spironolactone prolongs action } \\
\text { potential duration in isolated rab- } \\
\text { bit atrium. }\end{array}$ & \multicolumn{1}{c}{$\begin{array}{l}\text { Spironolactone derivative sodium } \\
\text { canrenoic acid prolongs action } \\
\text { potential duration in isolated rat } \\
\text { ventricle. }\end{array}$} \\
\hline Coraboeuf et al. 1974 & & \\
\hline Tillmann et al. 2002 & $\begin{array}{l}\text { Intravenous administration of } \\
\text { aldosterone leads to a lengthening } \\
\text { of monophasic action potential in } \\
\text { humans. }\end{array}$
\end{tabular}

Aldosterone and canrenoic acid Spironolactone and its main me-

Caballero et al. 2003 block native $\mathrm{I}_{\mathrm{K}, \mathrm{r}}$ in guinea-pig tabolite canrenoic acid block huventricular myocytes. man ether-a-go-go-related gene channels in stably transfected Chinese hamster ovary cells.

Spironolactone and its main metabolite canrenoic acid block hKv1.5 in stably transfected mouse fibroblasts and, respectively, Kv4.3 and Kv7.1+minK channels in transiently transfected Chinese hamster ovary cells. 
in a transgenic mouse model in vivo (Perrier et al. 2005). In a rat model of hyperaldosteronism of another group, treatment with aldosterone for three weeks also resulted in an upregulation of $\mathrm{I}_{\mathrm{Ca}, \mathrm{L}}$ without changes of the channel's biophysics (Martin-Fernandez et al. 2009). Contrary to these results, a physiological increase in serum aldosterone concentration in response to restriction in sodium intake did not affect $\mathrm{I}_{\mathrm{Ca}, \mathrm{L}}$ in the rat left ventricle in vivo (Wagner et al. 2008). Finally, in a rat model of myocardial infarction, long-term (3 weeks) MR antagonism prevented electrical remodeling that precedes cellular hypertrophy after myocardial infarction (Perrier et al. 2004).

Concerning transient outward potassium current $\mathrm{I}_{\text {to }}$, aldosterone exposition of ventricular rat myocytes resulted in a reduction of $\mathrm{I}_{\text {to }}$ without concomitant alterations of its biophysical properties. Aldosterone-induced reduction of $I_{\text {to }}$ was prevented by specific MR antagonism, sole effect of MR antagonism on $\mathrm{I}_{\text {to }}$ was not examined in this study (Benitah et al. 2001). In contrast, the same authors who also reported that a physiological increase in serum aldosterone concentration in response to restriction in sodium intake does not affect $\mathrm{I}_{\mathrm{Ca}, \mathrm{L}}$ also found no alterations of $\mathrm{I}_{\text {to }}$ (Wagner et al. 2008). Even more complicated seems to be a genderrelation and sex-hormone dependence of $\mathrm{I}_{\text {to }}$ alteration by aldosterone or MR antagonism: in streptozotocin-induced diabetic rat heart, spironolactone augmented $\mathrm{I}_{\mathrm{to}}$ in diabetic males (with a concomitant shortening of action potential duration) but had no effect in diabetic female animals. Effects of spironolactone were restored in ovariectomized diabetic females and abolished in orchidectomized diabetic males (Shimoni et al. 2008). Boixel et al. (2006) showed that incubation of isolated adult mouse ventricular myocytes with aldosterone resulted in a significant increase of cardiac sodium current $\mathrm{I}_{\mathrm{Na}}$ (without alterations of the biophysical properties) which was prevented by co-incubation with spironolactone.

Finally, "funny" current $\mathrm{I}_{\mathrm{f}}$ was transcriptionally upregulated via MR activation by aldosterone in physiological concentrations in cultured neonatal rat ventricular myocytes resulting in an increase of the rate of spontaneous beating, whereas the effect on $\mathrm{I}_{\mathrm{f}}$ was abolished by MR antagonists (Muto et al. 2007).

\section{Genomic effects on the atrial level}

In contrast to the comprehensive data on the ventricular level, there are only a few publications on the effect of aldosterone or MR antagonism on the atrial level: besides some in vitro data concerning the inhibitory effects of spironolactone and its main metabolite canrenoic acid on human ether-a-go-gorelated gene channels (Caballero et al. 2003) or hKv1.5, Kv4.3 and Kv7.1+minK channels (Gomez et al. 2005), the lacking effect of aldosterone exposition on $\mathrm{I}_{\mathrm{Ca}, \mathrm{L}}$ in atrial neonatal rat myocytes (in contrast to effects on ventricular myocytes in the same model) was described (Lalevee et al. 2005). Furthermore, our group showed recently that in a rabbit model of rapid atrial pacing, selective $M R$ antagonism with eplerenone alone does not alter $\mathrm{I}_{\text {to }}$ but reduces $\mathrm{I}_{\mathrm{Ca}, \mathrm{L}}$ and accordingly expected tachycardia-induced downregulation of $\mathrm{I}_{\mathrm{Ca}, \mathrm{L}}$ does not occur after eplerenone treatment whereas pacing-induced alterations of $\mathrm{I}_{\text {to }}$ cannot be prevented by this treatment (Laszlo et al. 2010).

Genomic effects of aldosterone and MR antagonism on atrial and ventricular electrophysiology are summarized in Table 2 .

\section{Effects of the modulation of oxidative stress by aldo- sterone or mineralocorticoid receptor antagonism on cardiac ion currents}

Recent studies report an association between AF and various endogenous states including oxidative stress and inflammation (Kim et al. 2003; Korantzopoulos et al. 2003, 2007; Lin et al. 2003; Neuman et al. 2007; Van Wagoner 2008). Oxidative stress refers to a situation when formation and bonding of reactive oxygen species is imbalanced. By reacting with macromolecules like lipids, nucleic acids and proteins including ion channels, free radicals provoke fibrosis and inflammation (Korantzopoulos et al. 2007). Aldosterone seems to promote inflammation and oxidative stress (Pitt et al. 2003b; Chai et al. 2006; Cachofeiro et al. 2008) where as in turn, MR antagonism seems to reduce oxidative stress (Korantzopoulos et al. 2004; Shimoni et al. 2008; Lendeckel et al. 2010). Both of these pathophysiological states can affect ion channels, therefore anti-inflammatory effects of MR antagonism or, respectively, its impact on oxidative stress might also alter atrial electrophysiology: reduction of oxidative stress is attended by a reduced activity / expression of NAD(P)H oxidase (Cai et al. 2003) resulting in diminished atrial superoxide concentrations (Takemoto et al. 2001). In turn, this lowers the amount of the oxidized form of glutathione and increases the reduced form. Thus, this shift of cellular redox state might finally alter important cardiac ion currents like transients $\mathrm{I}_{\text {to }}$ (Rozanski and $\mathrm{Xu}$ 2002), $\mathrm{I}_{\mathrm{Ca}, \mathrm{L}}$ (Hool 2008) or $\mathrm{I}_{\mathrm{Na}}$ (Qu et al. 1994). However, these theoretical considerations have to be confirmed in vivo, not only as Wagner et al. (2008) provided evidence that the activation of the MR per se depends on the intracellular redox state of cardiac myocytes.

\section{Summary and Conclusion}

MR antagonism has been introduced as a new therapeutic principle in "upstream" treatment of AF. Besides 
Table 2. Genomic effects of aldosterone or MR antagonism on cardiac electrophysiology in various experimental settings

\begin{tabular}{ll}
\hline \multicolumn{1}{c}{ Atrium } \\
\hline Benitah et al. 1999 & \\
\hline Benitah et al. 2001 & \\
\hline Perrier et al. 2004 & $\begin{array}{l}\text { In-vitro stimulation of cultured atrial neonatal } \\
\text { rat ventricular cardiomyocytes with aldoster- } \\
\text { one (24 hours) does not alter I } \mathrm{Ca,L} \text {. }\end{array}$ \\
\hline Lalevee et al. 2005 & $\begin{array}{l}\text { Selective MR antagonism (5 weeks) prolongs } \\
\text { effective refractory period in some regions } \\
\text { of the atrium remodeled by CHF but not in } \\
\text { normal atrium (canine model of congestive } \\
\text { heart failure). }\end{array}$ \\
\hline Shroff et al. 2006 et al. 2005
\end{tabular}

Boixel et al. 2006

Incubation of adult mice ventricular myocytes with aldosterone (24 hours) prolongs action potential duration and results in a significant increase of $\mathrm{I}_{\mathrm{Na}}$ (without alterations of the biophysical properties) which in turn is prevented by co-incubation with spironolactone.

In cultured neonatal rat ventricular myocytes, aldosterone in physi-

Muto et al. 2007 ological concentrations increases $\mathrm{I}_{\mathrm{f}}$ channel gene expression and the rate of spontaneous beating via MR activation. Increase of $\mathrm{I}_{\mathrm{f}}$ can be abolished by MR antagonists.

Incubation of rat left ventricular myocytes with aldosterone (24 hours) increases $\mathrm{I}_{\mathrm{Ca}, \mathrm{L}}$ in vitro. A physiological increase in serum

Wagner et al. 2008 aldosterone concentration in response to restriction in sodium intake does not affect $\mathrm{I}_{\mathrm{Ca}, \mathrm{L}}, \mathrm{I}_{\text {to }}$ and action potential duration in the rat left ventricle in vivo.

Shimoni et al. 2008

In streptozotocin-induced diabetic rat heart, spironolactone augments $\mathrm{I}_{\text {to }}$ in diabetic males (with a concomitant shortening of action potential duration) but has no effect in diabetic female animals.

Martin-Fernandez

et al. 2009 Chronic (3 weeks) aldosterone exposition of ventricular myocytes increases $\mathrm{I}_{\mathrm{Ca}, \mathrm{L}}$ and prolongs action potential duration (rat model of hyperaldosteronism).

In a rabbit model of rapid atrial pacing, selective MR antagonism with eplerenone alone does not alter $\mathrm{I}_{\mathrm{to}}$ but reduces $\mathrm{I}_{\mathrm{Ca}, \mathrm{L}}$ and Laszlo et al. 2010 accordingly expected tachycardia-induced downregulation of $\mathrm{I}_{\mathrm{Ca}, \mathrm{L}}$ does not occur after eplerenone treatment whereas pacing-induced alterations of $\mathrm{I}_{\mathrm{to}}$ cannot be prevented by this treatment.

positive effects on structural remodeling, effects of MR antagonism on atrial electrophysiology were described whereas the molecular mechanisms are currently unknown to a large extent. We delineated that the effect of aldosterone and accordingly of MR antagonism on atrial electrophysiology might be mediated, at least partly, by the affection of atrial ion channels or their regulative mechanisms. Summarized, publications concerning 
potential mechanisms of modulation of cardiac ion channels by aldosterone and MR antagonism in various experimental settings are almost exclusively limited to the ventricular level and partly, they are also contradictorily. However, translation of data obtained in ventricular myocytes to the atria is problematic because atrial and ventricular electrophysiology in general and, respectively, molecular composition or pharmacological properties of ion channels exhibit remarkable differences (Nattel et al. 2000; Schram et al. 2002; Lalevee et al. 2005; Hatano et al. 2006). Therefore it can be concluded that further research on the "atrial level" is needed in order to clarify the potential impact of the affection of atrial ion channels by aldosterone and accordingly MR antagonism in upstream therapy of AF.

\section{Disclosure information}

No potential conflict of interest including any financial, personal or other relationships with other people or organizations that could inappropriately influence, or be perceived to influence this work is being declared.

\section{References}

Allessie M., Ausma J., Schotten U. (2002): Electrical, contractile and structural remodeling during atrial fibrillation. Cardiovasc. Res. 54, 230-246 doi:10.1016/S0008-6363(02)00258-4

Amir O., Amir R. E., Paz H., Mor R., Sagiv M., Lewis B. S. (2008): Aldosterone synthase gene polymorphism as a determinant of atrial fibrillation in patients with heart failure. Am. J. Cardiol. 102, 326-329 doi:10.1016/j.amjcard.2008.03.063

Benitah J. P., Vassort G. (1999): Aldosterone upregulates $\mathrm{Ca}(2+)$ current in adult rat cardiomyocytes. Circ. Res. 85, $1139-1145$

Benitah J. P., Perrier E., Gomez A. M., Vassort G. (2001): Effects of aldosterone on transient outward $\mathrm{K}+$ current density in rat ventricular myocytes. J. Physiol. 537, 151-160 doi:10.1111/j.1469-7793.2001.0151k.x

Boixel C., Gavillet B., Rougier J. S., Abriel H. (2006): Aldosterone increases voltage-gated sodium current in ventricular myocytes. Am. J. Physiol. Heart Circ. Physiol. 290, H2257-2266 doi:10.1152/ajpheart.01060.2005

Bosch R. F., Scherer C. R., Rub N., Wohrl S., Steinmeyer K., Haase H., Busch A. E., Seipel L., Kuhlkamp V. (2003): Molecular mechanisms of early electrical remodeling: transcriptional downregulation of ion channel subunits reduces $\mathrm{I}(\mathrm{Ca}, \mathrm{L})$ and $\mathrm{I}($ to) in rapid atrial pacing in rabbits. J. Am. Coll. Cardiol. 41, 858-869

doi:10.1016/S0735-1097(02)02922-4
Briggs A. H., Holland W. C. (1959): Antifibrillatory effects of electrolyte-regulating steroids on isolated rabbit atria. Am. J. Physiol. 197, 1161-1164

Caballero R., Moreno I., Gonzalez T., Arias C., Valenzuela C., Delpon E., Tamargo J. (2003): Spironolactone and its main metabolite, canrenoic acid, block human ether-a-go-go-related gene channels. Circulation 107, 889-895 doi:10.1161/01.CIR.0000048189.58449.F7

Cachofeiro V., Miana M., de Las Heras N., Martin-Fernandez B., Ballesteros S., Fernandez-Tresguerres J., Lahera V. (2008): Aldosterone and the vascular system. J. Steroid Biochem. Mol. Biol. 109, 331-335 doi:10.1016/j.jsbmb.2008.03.005

Cai H., Griendling K. K., Harrison D. G. (2003): The vascular $\mathrm{NAD}(\mathrm{P}) \mathrm{H}$ oxidases as therapeutic targets in cardiovascular diseases. Trends Pharmacol. Sci. 24, 471-478 doi:10.1016/S0165-6147(03)00233-5

Chai W., Danser A. H. (2006): Why are mineralocorticoid receptor antagonists cardioprotective? Naunyn Schmiedebergs Arch. Pharmacol. 374, 153-162 doi:10.1007/s00210-006-0107-9

Coraboeuf E., Deroubaix E. (1974): Effect of a spirolactone derivative, sodium canrenoate, on mechanical and electrical activities of isolated rat myocardium. J. Pharmacol. Exp. Ther. 191, 128-138

Costa A. R., Torres L. B., Medei E., Ricardo R. A., Franca J. P., Smaili S., Nascimento J. H., Oshiro M. E., Bassani J. W., Ferreira A. T., Tucci P. J. (2009): The negative inotropic action of canrenone is mediated by L-type calcium current blockade and reduced intracellular calcium transients. Br. J. Pharmacol. 158, 580-587 doi:10.1111/j.1476-5381.2009.00329.x

Fuster V., Ryden L. E., Cannom D. S., Crijns H. J., Curtis A. B., Ellenbogen K. A., Halperin J. L., Le Heuzey J. Y., Kay G. N., Lowe J. E. et al. (2006): ACC/AHA/ESC 2006 guidelines for the management of patients with atrial fibrillation: full text: a report of the American College of Cardiology/ American Heart Association Task Force on practice guidelines and the European Society of Cardiology Committee for Practice Guidelines (Writing Committee to Revise the 2001 guidelines for the management of patients with atrial fibrillation) developed in collaboration with the European Heart Rhythm Association and the Heart Rhythm. Society. Europace 8, 651-745 doi:10.1093/europace/eul097

Goette A., Hoffmanns P., Enayati W., Meltendorf U., Geller J. C., Klein H. U. (2001): Effect of successful electrical cardioversion on serum aldosterone in patients with persistent atrial fibrillation. Am. J. Cardiol. 88, 906-909 doi:10.1016/S0002-9149(01)01905-1

Goette A., Bukowska A., Lendeckel U. (2007): Non-ion channel blockers as anti-arrhythmic drugs (reversal of structural remodeling). Curr. Opin. Pharmacol. 7, 219-224 doi:10.1016/j.coph.2006.09.006

Gomez A. M., Rueda A., Sainte-Marie Y., Pereira L., Zissimopoulos S., Zhu X., Schaub R., Perrier E., Perrier R., Latouche C., Richard S., Picot M. C., Jaisser F., Lai F. A., Valdivia H. H., Benitah J. P. (2009): Mineralocorticoid modulation 
of cardiac ryanodine receptor activity is associated with downregulation of FK506-binding proteins. Circulation 119, 2179-2187

doi:10.1161/CIRCULATIONAHA.108.805804

Gomez R., Nunez L., Caballero R., Vaquero M., Tamargo J., Delpon E. (2005): Spironolactone and its main metabolite canrenoic acid block hKv1.5, Kv4.3 and Kv7.1+minK channels. Br. J. Pharmacol. 146, 146-161 doi:10.1038/sj.bjp.0706302

Hatano S., Yamashita T., Sekiguchi A., Iwasaki Y., Nakazawa K., Sagara K., Iinuma H., Aizawa T., Fu L. T. (2006): Molecular and electrophysiological differences in the L-type Ca2+ channel of the atrium and ventricle of rat hearts. Circ. J. 70, 610-614 doi:10.1253/circj.70.610

Heusch G., Schulz R. (2006): [Pathophysiology of the renin-angiotensin-system in atrial fibrillation]. Dtsch. Med. Wochenschr. 131, 817-820 (in Germany) doi:10.1055/s-2006-939853

Hool L. C. (2008): Evidence for the regulation of L-type Ca2+ channels in the heart by reactive oxygen species: mechanism for mediating pathology. Clin. Exp. Pharmacol. Physiol. 35, 229-234

Issac T. T., Dokainish H., Lakkis N. M. (2007): Role of inflammation in initiation and perpetuation of atrial fibrillation: a systematic review of the published data. J. Am. Coll. Cardiol. 50, 2021-2028 doi:10.1016/j.jacc.2007.06.054

Kim Y. H., Lim D. S., Lee J. H., Shim W. J., Ro Y. M., Park G. H., Becker K. G., Cho-Chung Y. S., Kim M. K. (2003): Gene expression profiling of oxidative stress on atrial fibrillation in humans. Exp. Mol. Med. 35, 336-349

Korantzopoulos P., Kolettis T., Siogas K., Goudevenos J. (2003): Atrial fibrillation and electrical remodeling: the potential role of inflammation and oxidative stress. Med. Sci. Monit. 9, RA225-229

Korantzopoulos P., Kolettis T., Kountouris E., Siogas K. (2004): Atrial remodeling in persistent atrial fibrillation: the potential role of aldosterone. Eur. Heart J. 25, 1086-1087 doi:10.1016/j.ehj.2003.12.033

Korantzopoulos P., Kolettis T. M., Galaris D., Goudevenos J. A. (2007): The role of oxidative stress in the pathogenesis and perpetuation of atrial fibrillation. Int. J. Cardiol. 115, 135-143 doi:10.1016/j.ijcard.2006.04.026

Krishnamoorthy S., Lip G. Y. (2009): Renin-angiotensin-aldosterone system blockade in atrial fibrillation and left atrial remodelling. Int. J. Clin. Pract. 63, 982-985 doi:10.1111/j.1742-1241.2009.02083.x

Lalevee N., Rebsamen M. C., Barrere-Lemaire S., Perrier E., Nargeot J., Benitah J. P., Rossier M. F. (2005): Aldosterone increases Ttype calcium channel expression and in vitro beating frequency in neonatal rat cardiomyocytes. Cardiovasc. Res. 67, 216-224 doi:10.1016/j.cardiores.2005.05.009

Laszlo R., Eick C., Schwiebert M., Schreiner B., Weig H. J., Weretka S., Schreieck J. (2008): Transient outward potassium current in rabbit atrium is depressed after short-time rapid atrial pac- ing but recovers after a longer pacing period. Gen. Physiol. Biophys. 27, 174-178

Laszlo R., Bentz K., Konior A., Eick C., Schreiner B., Kettering K., Schreieck J. (2010): Effects of selective mineralocorticoid receptor antagonism on atrial ion currents and early ionic tachycardia-induced electrical remodelling in rabbits. Naunyn Schmiedebergs Arch. Pharmacol. 382, 347-356 doi:10.1007/s00210-010-0553-2

Lemarie C. A., Paradis P., Schiffrin E. L. (2008): New insights on signaling cascades induced by cross-talk between angiotensin II and aldosterone. J. Mol. Med. 86, 673-678 doi:10.1007/s00109-008-0323-5

Lendeckel U., Dobrev D., Goette A. (2010): Aldosterone-receptor antagonism as a potential therapeutic option for atrial fibrillation. Br. J. Pharmacol. 159, 1581-1583 doi:10.1111/j.1476-5381.2010.00675.x

Li D., Shinagawa K., Pang L., Leung T. K., Cardin S., Wang Z., Nattel S. (2001): Effects of angiotensin-converting enzyme inhibition on the development of the atrial fibrillation substrate in dogs with ventricular tachypacing-induced congestive heart failure. Circulation 104, 2608-2614 doi:10.1161/hc4601.099402

Lin P. H., Lee S. H., Su C. P., Wei Y. H. (2003): Oxidative damage to mitochondrial DNA in atrial muscle of patients with atrial fibrillation. Free Radic. Biol. Med. 35, 1310-1318 doi:10.1016/j.freeradbiomed.2003.07.002

Martin-Fernandez B., Miana M., De Las Heras N., Ruiz-Hurtado G., Fernandez-Velasco M., Bas M., Ballesteros S., Lahera V., Cachofeiro V., Delgado C. (2009): Cardiac L-type calcium current is increased in a model of hyperaldosteronism in the rat. Exp. Physiol. 94, 675-683 doi:10.1113/expphysiol.2009.047688

McManus F., McInnes G. T., Connell J. M. (2008): Drug Insight: eplerenone, a mineralocorticoid-receptor antagonist. Nat. Clin. Pract. Endocrinol. Metab. 4, 44-52 doi:10.1038/ncpendmet0676

Milliez P., Girerd X., Plouin P. F., Blacher J., Safar M. E., Mourad J. J. (2005): Evidence for an increased rate of cardiovascular events in patients with primary aldosteronism. J. Am. Coll. Cardiol. 45, 1243-1248 doi:10.1016/j.jacc.2005.01.015

Muto T., Ueda N., Opthof T., Ohkusa T., Nagata K., Suzuki S., Tsuji Y., Horiba M., Lee J. K., Honjo H., Kamiya K., Kodama I., Yasui K. (2007): Aldosterone modulates I(f) current through gene expression in cultured neonatal rat ventricular myocytes. Am. J. Physiol. Heart Circ. Physiol. 293, $\mathrm{H} 2710-2718$ doi:10.1152/ajpheart.01399.2006

Nattel S., Matthews C., De Blasio E., Han W., Li D., Yue L. (2000): Dose-dependence of 4-aminopyridine plasma concentrations and electrophysiological effects in dogs : potential relevance to ionic mechanisms in vivo. Circulation 101, 1179-1184

Nattel S., Burstein B., Dobrev D. (2008): Atrial remodeling and atrial fibrillation: mechanisms and implications. Circ. Arrhythm. Electrophysiol. 1, 62-73 doi:10.1161/CIRCEP.107.754564 
Nerbonne J. M., Kass R. S. (2005): Molecular physiology of cardiac repolarization. Physiol. Rev. 85, 1205-1253 doi:10.1152/physrev.00002.2005

Neuman R. B., Bloom H. L., Shukrullah I., Darrow L. A., Kleinbaum D., Jones D. P., Dudley S. C. Jr. (2007): Oxidative stress markers are associated with persistent atrial fibrillation. Clin. Chem. 53, 1652-1657

doi:10.1373/clinchem.2006.083923

Ouvrard-Pascaud A., Sainte-Marie Y., Benitah J. P., Perrier R. Soukaseum C., Cat A. N., Royer A., Le Quang K., Charpentier F., Demolombe S., Mechta-Grigoriou F., Beggah A. T., MaisonBlanche P., Oblin M. E., Delcayre C., Fishman G. I., Farman N., Escoubet B., Jaisser F. (2005): Conditional mineralocorticoid receptor expression in the heart leads to life-threatening arrhythmias. Circulation 111, 3025-3033 doi:10.1161/CIRCULATIONAHA.104.503706

Ovaert P., Elliott J., Bernay F., Guillot E., Bardon T. (2010): Aldosterone receptor antagonists--how cardiovascular actions may explain their beneficial effects in heart failure. J. Vet. Pharmacol. Ther. 33, 109-117 doi:10.1111/j.1365-2885.2009.01122.x

Pei D. A., Li L., Xu Z. Y., Zou L. J., Zhang B. R., Huang S. D., Hao J. H., Wang Z. N., Lu F. L. (2007): Expression of mineralocorticoid receptor and 11-beta-hydroxysteroid dehydrogenase type 2 in human atria during chronic atrial fibrillation: study of 25 cases. Zhonghua Yi Xue Za Zhi 87, 816-819 (in Chinese)

Perrier E., Kerfant B. G., Lalevee N., Bideaux P., Rossier M. F., Richard S., Gomez A. M., Benitah J. P. (2004): Mineralocorticoid receptor antagonism prevents the electrical remodeling that precedes cellular hypertrophy after myocardial infarction. Circulation 110, 776-783

doi:10.1161/01.CIR.0000138973.55605.38

Perrier R., Richard S., Sainte-Marie Y., Rossier B. C., Jaisser F., Hummler E., Benitah J. P. (2005): A direct relationship between plasma aldosterone and cardiac L-type Ca2+ current in mice. J. Physiol. 569, 153-162 doi:10.1113/jphysiol.2005.092692

Pitt B., Zannad F., Remme W. J., Cody R., Castaigne A., Perez A., Palensky J., Wittes J. (1999): The effect of spironolactone on morbidity and mortality in patients with severe heart failure. Randomized Aldactone Evaluation Study Investigators. N. Engl. J. Med. 341, 709-717

Pitt B., Remme W., Zannad F., Neaton J., Martinez F., Roniker B., Bittman R., Hurley S., Kleiman J., Gatlin M. (2003a): Eplerenone, a selective aldosterone blocker, in patients with left ventricular dysfunction after myocardial infarction. N. Engl. J. Med. 348, 1309-1321 doi:10.1056/NEJMoa030207

Pitt B., Stier C. T., Jr., Rajagopalan S. (2003b): Mineralocorticoid receptor blockade: new insights into the mechanism of action in patients with cardiovascular disease. J. Renin Angiotensin Aldosterone Syst. 4, 164-168 doi:10.3317/jraas.2003.025

Qu Y., Rogers J., Tanada T., Scheuer T., Catterall W. A. (1994): Modulation of cardiac $\mathrm{Na}+$ channels expressed in a mammalian cell line and in ventricular myocytes by protein kinase C. Proc. Natl. Acad. Sci. U.S.A. 91, 3289-3293 doi:10.1073/pnas.91.8.3289

Rozanski G. J., Xu Z. (2002): A metabolic mechanism for cardiac $\mathrm{K}+$ channel remodelling. Clin. Exp. Pharmacol. Physiol. 29, 132-137 doi:10.1046/j.1440-1681.2002.03618.x

Schram G., Pourrier M., Melnyk P., Nattel S. (2002): Differential distribution of cardiac ion channel expression as a basis for regional specialization in electrical function. Circ. Res. 90, 939-950

doi:10.1161/01.RES.0000018627.89528.6P

Shimoni Y., Chen K., Emmett T., Kargacin G. (2008): Aldosterone and the autocrine modulation of potassium currents and oxidative stress in the diabetic rat heart. Br. J. Pharmacol. 154, 675-687 doi:10.1038/bjp.2008.114

Shroff S. C., Ryu K., Martovitz N. L., Hoit B. D., Stambler B. S. (2006): Selective aldosterone blockade suppresses atrial tachyarrhythmias in heart failure. J. Cardiovasc. Electrophysiol. $17,534-541$ doi:10.1111/j.1540-8167.2006.00372.x

Stier C. T., Jr., Chander P. N., Rocha R. (2002): Aldosterone as a mediator in cardiovascular injury. Cardiol. Rev. 10, 97-107 doi:10.1097/00045415-200203000-00008

Struthers A. D., MacDonald T. M. (2004): Review of aldosteroneand angiotensin II-induced target organ damage and prevention. Cardiovasc. Res. 61, 663-670 doi:10.1016/j.cardiores.2003.11.037

Takemoto M., Node K., Nakagami H., Liao Y., Grimm M., Takemoto Y., Kitakaze M., Liao J. K. (2001): Statins as antioxidant therapy for preventing cardiac myocyte hypertrophy. J. Clin. Invest. 108, 1429-1437

Tillmann H. C., Schumacher B., Yasenyev O., Junker M., Christ M., Feuring M., Wehling M. (2002): Acute effects of aldosterone on intracardiac monophasic action potentials. Int. J. Cardiol. 84, 39-40 doi:10.1016/S0167-5273(02)00115-8

Van Wagoner D. R. (2008): Oxidative stress and inflammation in atrial fibrillation: role in pathogenesis and potential as a therapeutic target. J. Cardiovasc. Pharmacol. 52, 306-313 doi:10.1097/FJC.0b013e31817f9398

Wagner M., Rudakova E., Volk T. (2008): Aldosterone-induced changes in the cardiac L-type $\mathrm{Ca}(2+)$ current can be prevented by antioxidants in vitro and are absent in rats on low salt diet. Pflugers Arch. 457, 339-349 doi:10.1007/s00424-008-0518-1

Wehling M., Spes C. H., Win N., Janson C. P., Schmidt B. M., Theisen K., Christ M. (1998): Rapid cardiovascular action of aldosterone in man. J. Clin. Endocrinol. Metab. 83, 3517-3522 doi:10.1210/jc.83.10.3517

Wijffels M. C., Kirchhof C. J., Dorland R., Allessie M. A. (1995): Atrial fibrillation begets atrial fibrillation. A study in awake chronically instrumented goats. Circulation 92, 1954-1968

Workman A. J., Kane K. A., Rankin A. C. (2008): Cellular bases for human atrial fibrillation. Heart Rhythm 5, S1-6 doi:10.1016/j.hrthm.2008.01.016 
Wozakowska-Kaplon B., Bartkowiak R., Janiszewska G (2010). A Decrease in Serum Aldosterone Level is Associated with Maintenance of Sinus Rhythm after Successful Cardioversion of Atrial Fibrillation. Pacing Clin. Electrophysiol. 33, 561-565 doi:10.1111/j.1540-8159.2009.02673.x

Zannad F. (1991): Vascular and cardiac actions of aldosterone and spironolactone. Z Kardiol 80 (Suppl. 7), 103-105
Zhao J., Li J., Li W., Li Y., Shan H., Gong Y., Yang B (2010). Effects of spironolactone on atrial structural remodelling in a canine model of atrial fibrillation produced by prolonged atrial pacing. Br. J. Pharmacol. 159, 1584-1594 doi:10.1111/j.1476-5381.2009.00551.x

Received: April 28, 2010

Final version accepted: September 13, 2010 